\title{
PENGARUH BRAND EQUITY DAN PROMOTION MIX TERHADAP KEPUTUSAN PEMBELIAN SMARTPHONE XIOMI PADA MAHASISWA MANAJEMEN STIE-KBP PADANG
}

\author{
Efendi, Febsri Susanti \\ Sekolah Tinggi Ilmu Ekonomi KBP \\ febsrisusanti@akbpstie.ac.id
}

\begin{abstract}
The purpose of this study was to analyze the influence of Brand Equity, Promotion Mix on Xiomi Smartphone Purchasing Decisions on STIE - KBP Padang management students. The sampling technique was obtained by using the Sampling method with a total sample of 86 respondents. The results of hypothesis testing showed that the variable Brand Equity (X1), Promotion Mix (X2), had a significant value $t$ greater than Sig.a (0.05) so it can be said that these variables have a partially significant influence on the intention of Xiomi Smartphone Purchasing Decisions on STIE - KBP Padang management students. The results of the calculation of multiple linear regression analysis that has been carried out shows that the ability of the model in explaining the influence of independent variables on the dependent variable is large, it can be seen in the value of Adj. $R$. Square (R2) that is equal to 0.848 (35\%). Thus, it means that the regression model used is able to explain the effect of Brand Equity (X1), Promotion Mix (X2), on the Purchase Decision of 35\%, while the remaining 65\% is explained by other variables not included in this study.
\end{abstract}

Keywords: Brand Equity, Promotion Mix, and Purchase Decisions

\section{PENDAHULUAN}

Dizaman moderen saat ini, kemajuan pesat dalam telekomunikasi dianggap membantu hidup manusia. Sejak ditemukannya alat komunikasi, kegiatan dan gerak hidup manusia menjadi lebih mudah dan terasa lebih dekat. Telepon selular merupakan perkembangan dari telepon rumah yang dapat dibawa kemana saja, karena handphone bersifat mobile bukan hanya untuk menelpon namun dapat mengirim sms/pesan, internet, mendengarkan musik, bahkan mengabadikan kegiatan manusia dengan teknologi kamera.

Merek adalah alat utama yang digunakan oleh pemasar untuk membedakan produk mereka dari produk pesaingnya. Suatu produk dengan brand equity (ekuitas merek) yang kuat dapat membentuk brand platform (landasan merek) yang kuat dan mampu mengembangkan keberadaan suatu merek dalam persaingan dengan jangka waktu yang lama. Perusahaan memperebutkan konsumen pada saat ini tidak lagi terbatas pada atribut fungsional produk seperti kegunaan suatu produk, melainkan dengan merek yang mampu memberikan citra 
terhadap suatu produk. Para produsen telepon seluler saling berlomba menciptakan seri dan model terbaru dengan fitur-fitur yang canggih.

Banyak konsumen yang belum sempat mencoba seri terbaru dari sebuah merek ponsel, mereka sudah dihadapkan pada seri terbaru lainnya dari merek yang sama. Belum lagi merek-merek lain yang tidak mau kalah bersaing memasarkan produk-produk terbarunya. Pada umumnya masyarakat belum mengerti tentang kualitas produk yang akan mereka beli, mereka melakukan pembelian berdasarkan merek, model dan promosi. Model (desaign) yang menarik memberikan nilai tambah bagi konsumen dalam melakukan pembelian. Penelitian ini bertujuan untuk mengetahui apakah Brand Equity berpengaruh terhadap keputusan pembelian smartphone Xiomi. Sebagus apapun suatu produk yang ditawarkan, jika konsumen tidak pernah mendengar dan mengetahui manfaat suatu produk, maka konsumen tidak akan membelinya. Promosi adalah sebuah kegiatan yang dilakukan untuk menyampaikan atau mengkomunikasikan suatu produk kepada pasar sasaran untuk memberi informasi tentang keistimewaan, kegunaan, dan keberadaan produk itu sendiri. Dilihat dari arti promosi komunikasi yang persuasif, mengajak, mendesak, membujuk dan menyakinkan seseorang. Perusahaan harus melakukan pendekatan konsumen dengan cara memberikan informasi antara lain, mengenai produk baru, memperkenalkan cara penggunaan produk dan lain-lain, (Mursid, 2006) perusahaan perlu melakukan pendekatan kepada konsumen secara berkelanjutan serta promosi yang merupakan faktor yang berperan besar didalamnya. Sebelum mencetak suatu produk perlu dianalisa apakah produk tersebut memang dibutuhkan oleh masyarakat dan mendapatkan pasar yang sesuai (Mangold, 2009).

Smartphone xiomi adalah salah satu merek handphone yang berasal dari negara China yang sudah masuk ke indonesia. Persaingan didunia teknologi yang semakin lama kian menarik dan Smartphone xiomi salah satu pabrikan handphone yang namanya sudah mulai dikenal dikalangan masyarakat khususnya pada mahasiswa manajemen STIE-KBP Padang. Saya pernah melakukan wawancara kepada beberapa mahasiswa manajemen STIE-KBP Padang sekitar 10 orang yang memakai Smartphone Xiomi dan menanyakan tentang Smartphone Xiomi kelebihan dan kekurangan Smartphone Xiomi ini. Dan hasil yang saya dapatkan sangat positif, mereka sangat senang dengan fitur-fitur yang ada dalam Smartphone Xiomi terutama pada bagian kamera yang mana hasil gambarnya sangat bagus dan tajam.Baterainya yang kuat dan juga tahan lama.Itulah yang membuat mereka memutuskan untuk membeli Smartphone Xiomi.Untuk dapat meningkatkan penjualan, Smartphone xiomi harus lebih memperhatikan strategi untuk dapat meningkatkan penjualan.Sesuai dengan literatur yang ada, keputusan pembelian dapat dipengaruhi oleh bauran-bauran promosi seperti periklanan, penjualan pribadi, hubungan masyarakat, dan promosi penjualan.

Menurut penelitian terdahulu yang dilakukan oleh (Widya Dewi Agustin, 2011) Berjudul "Pengaruh Bauran Promosi Terhadap Minat beli deodoran Rexona Teens Pada Siswi SMK 2 Buduran Sidoarjo“ menyatakan bahwa adanya pengaruh yang signifikan secara simultan dari variabel periklanan (X1), promosi penjualan (X2).

Berdasarkan latar belakang yang telah diuraikan, maka dapat dirumuskan dalam penelitian ini adalah: 1) Apakah Brand Equity berpengaruh terhadap keputusan pembelian Smartphone Xiomi pada mahasiswa manajemen STIE-KBP 
Padang? 2) ApakahPromotion Mix (Advertising, Sales Promotion, Public Realation and Publisity, Personal Selling, Direct Marketing) berpengaruh terhadap keputusan pembelian Smartphone Xiomi pada mahasiswa manajemen STIE - KBP Padang?.

\section{LANDASAN TEORI DAN HIPOTESIS Keputusan Pembelian}

Kehidupan manusia tidak lepas dari melakukan jual beli. Sebelum melakukan pembelian, seseorang biasanya akan melakukan keputusan pembelian terlebih dahulu terhadap suatu produk. Keputusan pembelian merupakan kegiatan individu yang secara langsung terlibat dalam pengambilan keputusan untuk melakukan pembelian terhadap produkyang ditawarkan oleh penjual. Pengertian keputusan pembelian, menurut(Kotler \& Amstrong, 2011) adalah tahap dalam proses pengambilan keputusan pembeli di mana konsumen benar-benar membeli.

Pengambilan keputusan merupakan suatu kegiatan individu yang secara langsung terlibat dalam mendapatkan dan mempergunakan barang yang ditawarkan. Definisi lain keputusan pembelian adalah keputusan pembeli tentang merek mana yang dibeli. Konsumen dapat membentuk niat untuk membeli merek yang paling disukai. Keputusan pembelian merupakan suatu proses pengambilan keputusan akan pembelian yang mencakup penentuan apa yang akan dibeli atau tidak melakukan pembelian (Kotler dan Amstrong, 2008)

Menurut (Peter and Olson, 2000) keputusan pembelian adalah proses mengkombinasikan pengetahuan untuk mengevaluasi dua atau lebih perilaku alternatif dan memilih salah satu diantaranya. (Setiadi, 2003) menuturkan pengambilan keputusan yang diambil oleh konsumen dapat disebut sebagai pemecahan masalah. Dalam proses pengambilan keputusan, konsumen memiliki sasaran atau perilaku mana yang ingin dilakukan untuk mencapai sasaran tersebut. Dengan demikian hal ini dapat membantu memecahkan masalahnya.

Selanjutnya dijelaskan pemecahan masalah merupakan suatu aliran timbal balik yang berkesinambungan diantara faktor lingkungan, proses kognitif dan afektif serta tindakan perilaku. Pada tahap pertama merupakan pemahaman adanya masalah. Selanjutnya terjadi evaluasi terhadap alternatif yang ada dan tindakan yang paling sesuai dipilih.

Menurut (Assauri, 2004) Keputusan pembelian merupakan suatu proses pengambilan keputusan akan pembelian yang mencakup penentuan apa yang akan dibeli atau tidak melakukan pembelian dan keputusan itu diperoleh dari kegiatan-kegiatan sebelumnya. Dari beberapa pengertian pengambilan keputusan yang telah dipaparkan diatas, maka dapat diambil kesimpulan bahwa keputusan pembelian adalah suatu proses pengambilan keputusan akan pembelian yang akan menentukan dibeli atau tidaknya pembelian tersebut yang diawali dengan kesadaran atas pemenuhan atau keinginan. (Kotler, 2005) menyatakan bahwa perilaku pembelian konsumen dipengaruhi oleh faktor- faktor berikut :

\section{Faktor budaya}

Faktor-faktor budaya mempunyai pengaruh yang paling luas dan paling dalam. Budaya merupakan penentu keinginan dan perilaku yang paling dasar. Budaya mencakup kebangsaan, agama, kelompok ras, dan wilayah geografis. Sedangkan kelas sosial adalah pembagian masyarakat 
yang relatif homogen dan permanen, yang tersusun secara hirarkis dan yang para anggotanya menganut nilai, minat, dan perilaku yang serupa.

\section{Faktor sosial}

Selain faktor budaya, perilaku konsumen dipengaruhi oleh faktorfaktor sosial seperti kelompok acuan, keluarga, serta peran dan status sosial masyarakat.

a. Kelompok Acuan

Kelompok acuan mempengaruhi pendirian dan konsep pribadi seseorang karena individu biasanya berhasrat untuk berperilaku sama dengan kelompok acuan tersebut (kotler, 2007)

b. Keluarga

Keluarga sendiri biasanya menjadi sumber orientasi dalam perilaku. Anak akan cenderung berperilaku sama dengan orang tua, ketika melihat perilaku orang tua mereka mendapatkan manfaat atau keuntungan (Kotler, 2007).

c. Peran dan status dalam masyarakat

Peranan adalah kegiatan yang diharapkan untuk dilakukan mengacu pada orang-orang di sekellilingnya.Sedang status adalah pengakuan umum masyarakat sesuai dengan peran yang dijalankan. Setiap individu dan status yang disandangnya akanmempengaruhi perilakunya (Kotler, 2007)

\section{Faktor pribadi}

Keputusan pembeli juga dipengaruhi oleh karakteristik pribadi. Karakteristik tersebut meliputi usia dan tahap siklus hidup, pekerjaan, keadaan ekonomi, gaya hidup, serta kepribadian dan konsep-diri pembeli.

a. Usia serta Tahap Siklus Hidup Individu dalam membeli barang atau jasa biasanya disesuaikan dengan perubahan usia. Pola konsumsi yang berbeda antara individuyang usianya berbeda (Kotler, 2007)

b. Pekerjaan

Pekerjaan individu tentunya ikut mempengaruhi perilaku pembelian individu. Penghasilan yang mereka peroleh dari pekerjaannya itulah yang menjadi determinan penting dalam perilaku pembelian mereka (Kotler, 2007)

c. Gaya Hidup

Gaya hidup merupakan pola kehidupan seseorang sebagaimana tercermin dalam aktivitas, minat, dan opininya. Gaya hidup akan sangat mempengaruhi pola tindakan dan perilaku individu(Kotler, 2007)

d. Kepribadian

Kepribadian adalah karakteristik psikologi yang berbeda dari seseorang yang menyebabkan tanggapan yang relatif konsisten dan tetap terhadap lingkungannya (Kotler, 2007)

\section{Faktor psikologis}

Pilihan pembelian seseorang dipengaruhi oleh empat faktor psikologi utama. Terdiri dari motivasi, persepsi, pembelajaran, serta keyakinan dan sikap. Kebutuhan akan menjadi motif utama untuk mencapai tahap intensitas yang memadai. Motivasi adalah kebutuhan yang memadai untuk mendorong seseorang bertindak. Persepsi adalah proses yang digunakan oleh individu untuk memilih, mengorganisasi, dan 
menginterpretasi masukan informasi guna menciptakan gambaran dunia yang memiliki arti.

Dalam memutuskan keputusan pembelian konsumen tidak langsung memutuskan untuk melakukan pembelian, Menurut (Kotler dan Armstrong, 2008) ada lima tahapanproses keputusan pembelian, yaitu :

\section{Gambar 1}

Proses Keputusan Pembelian

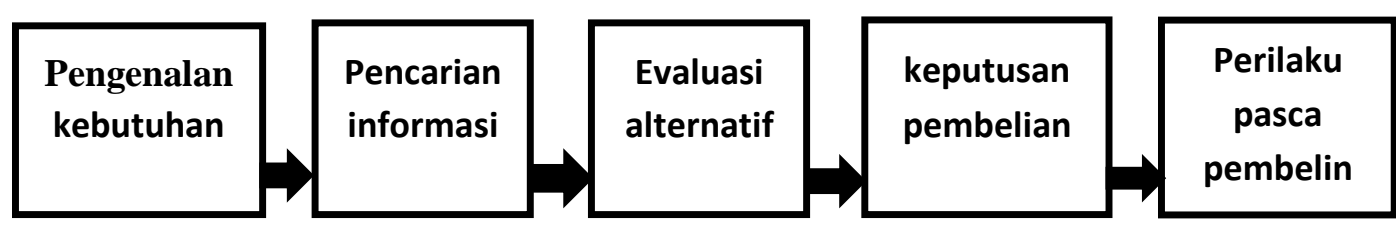

Sumber : (Kotler dan Armstrong, 2008)Pengenalan Kebutuhan (NeedRecognition)

1. Pengenalan Masalah

Pembeli menyadari suatu masalah atau kebutuhan. Kebutuhan dapat dipicuoleh rangsangan internal dan eksternal. Rangsangan internal ditunjukanketika salah satu kebutuhan normal seseorang muncul seperti lapar atau haus. Rangsangan eksternal merupakan dorongan dari suatu iklan atau diskusi antar individu.

2. Pencarian Informasi (Information Search) Konsumen yang tertarik mungkin mencari lebih banyak informasi atau mungkin tidak. Konsumen dapat memperoleh informasi dari beberapa sumber, yaitu sumber pribadi (keluarga, teman, rekan), sumber komersial (iklan, wiraniaga, kemasan), sumber publik (media massa, organisasi pemeringkat konsumen), atau sumber pengalaman (penanganan, pemeriksaan, pemakaian produk). Ketika semakin banyak informasi yang diperoleh konsumen, kesadaran dan pengetahuan konsumen akan merekdan fitur yang tersedia akan meningkat.

3. Evaluasi Alternatif (Alternative Evaluation), Bagaimana konsumen mengevaluasi berbagai alternative merek yang tersedia. Pengenalan Kebutuhan Pencarian Informasi Evaluasi Alternatif Keputusan Pembelian Perilaku Pasca pembelian.

4. Keputusan Pembelian (Purchase Decision) Dua faktor yang mempengaruhi hal tersebut. Pertama, sikap orang lain, maksudnya seseorang yang dapat mempengaruhi konsumen dalam melakukan keputusan pembelian. Kedua, situasional yang tidak diharapkan, maksudnya adanya hal-hal yang tak terduga dapat mengubah keputusan pembelian.

5. Perilaku Pasca pembelian (Postpurchase Behavior) Merupakan hubungan antara ekspektasi konsumen dan kinerja produk. Jika produk tidak memenuhi eskpektasi, konsumen akan kecewa. Jika produk memenuhi ekspektasi, konsumen akan puas. Jika produk melebihi ekspektasi, konsumen akan sangat puas.

\section{Brand Equity}

Brand Equity adalah seperangkat asosiasi dan perilaku yang dimiliki oleh pelanggan merek, anggota saluran distribusi, dan perusahaan yang memungkinkan suatu merek mendapatkan kekuatan, daya tahan, dan keunggulan yang dapat membedakan dengan merek pesaing (Astuti dan Cahyadi, 2007). 
(Kotler dan Keller, 2007), mendefinisikan ekuitas merek sebagai nilai tambah yang diberikan kepada produk dan jasa. Nilai ini bias dicerminkan dalam bentuk cara seorang konsumen dalam berpikir, merasa, dan bertindak terhadap merek, harga, pangsa pasar, dan profitabilitas yang dimiliki perusahaan. (Knapp, 2001) mendefinisikan ekuitas merek sebagai totalitas dari persepsi merek, mencangkup kualitas relative dari produk dan jasa, kinerja keuangan, loyalitas pelanggan, kepuasan dan keseluruhan penghargaan terhadap merek.

Sedangkan jika para pelanggan cenderung membeli suatu merek walaupun dihadapkan pada para pesaing yang menawarkan produk yang lebih unggul, misalnya dalam hal harga dan kepraktisan, maka merek tersebut memiliki nilai ekuitas yang tinggi (Astuti dan Cahyadi, 2007)

Pendekatan ekuitas merek yang akan digunakan dalam penelitian ini adalah pendekatan ekuitas merek berbasis pelanggan. Pendekatan ekuitas merek berbasis pelanggan akan memandang ekuitas merek dari sudut konsumen. Dasar pemikiran model ekuitas merek berbasis pelanggan mengungkapkan bahwa kekuatan suatu merek terletak pada apa yang telah dilihat, dibaca, didengar, dipelajari, dipikirkan, dan dirasakan konsumen tentang merek selama ini (Kotler dan Keller, 2007)

Menurut (Kotler dan Keller, 2007) ekuitas merek berbasis pelanggan dapat didefinisikan sebagai perbedaan dampak dari pengetahuan merek terhadap tanggapan konsumen pada merek tersebut. Suatu merek dapat dikatakan memiliki ekuitas merek berbasis pelanggan yang positif apabila konsumen bereaksi lebih menyenangkan terhadap produk tertentu. Sebaliknya, suatu merek dapat dikatakan memiliki ekuitas merek berbasis pelanggan yang negative apabila konsumen bereaksi secara kurang menyenangkan terhadap aktivitas pemasaran merek dalam situasi yang sama.

Empat elemen inti Brand Equit (brand awareness, brand association, perceived quality, dan brand loyalty) yang kuat dapat meningkatkan kekuatan elemen ekuitas merek lainnya seperti kepercayaan konsumen, dan lain-lain.

Ekuitas merek dapat mempengaruhi rasa percaya diri konsumen dalam pengambilan keputusan pembelian atas dasar pengalaman masa lalu dalam penggunaan atau kedekatan, dan asosiasi dengan berbagai karakteristik merek (Durianto, dkk, 2004) Semakin kuat ekuitas merek suatu produk, maka semakin kuat pula daya tariknya dimata konsumen untuk mengkonsumsi produk tersebut dan pada akhirnya akan mengarah pada keputusan pembelian produk (Durianto, dkk, 2004)

\section{Kesadaran Merek (Brand Awareness)}

Kesadaran merek merupakan elemen ekuitas yang sangat penting bagi perusahaan karena kesadaran merek dapat berpengaruh secara langsung terhadap ekuitas merek. Apabila kesadaran konsumen terhadap merek rendah, maka dapat dipastikan bahwa ekuitas mereknya juga akan rendah.

Kesadaran konsumen terhadap merek dapat digunakan oleh perusahaan sebagai sarana untuk memberikan pemahaman yang lebih mendalam mengenai suatu merek kepada konsumen (Humdiana, 2005)

Berikut adalah nilai-nilai kesadaran merek yang diciptakan oleh perusahaan (Humdiana, 2005): 
a. Jangkar yang menjadi pengait asosiasi lain.

Tingkat kesadaran merek yang tinggi akan lebih memudahkan pemasar untuk melekatkan suatu asosiasi terhadap merek karena merek tersebut telah tersimpan dibenak konsumen.

b. Rasa suka

Kesadaran merek yang tinggi dapat menimbulkan rasa suka konsumen terhadap merek tersebut.

c. Komitmen

Jika kesadaran suatu merek tinggi, maka konsumen dapat selalu merasa kehadiran merek tersebut.

d. Mempertimbangkan merek

Ketika konsumen akan melakukan keputusan pembelian, merek yang memiliki tingkat kesadaran merek tinggi akan selalu tersimpan di benak konsumen dan akan dijadikan pertimbangan oleh konsumen.

Aspek paling penting dari brand awareness adalah bentuk informasi dalam ingatan di tempat yang pertama (Lindawati, 2005)

\section{Asosiasi Merek (Brand Association)}

Sebuah merek adalah serangkaian asosiasi, biasanya terangkai dalam berbagai bentuk yang bermakna. Suatu merek yang lebih mapan akan mempunyai posisi yang menonjol dalam suatu kompetisi karena didukung oleh berbagai asosisasi yang kuat (Humdiana, 2005)

Asosiasi merek dapat memberikan nilai bagi suatu merek dari sisi perusahaan maupun dari sisi konsumen, berikut adalah berbagai fungsi dari asosiasi tersebut (Humdiana, 2005):

a. Membantu proses penyusunan informasi.

b. Membedakan merek dengan merek lain.

c. Alasan pembelian,

d. Menciptakan sikap atau perasaan positif karena pengalaman ketika menggunakan produk.

e. Landasan perusahaan untuk melakukan perluasan merek.

Menurut konsep Brand Equity yang dikembangkan oleh David A. Aaker, kategori asosiasi merek mewakili 3 elemen, yaitu sebagai berikut (Durianto, dkk, 2004):

a. Persepsi nilai

Persepsi nilai suatu produk merupakan suatu persepsi yang melibatkan manfaat fungsional dimata konsumen.Nilai merupakan hal penting untuk suatu merek. Merek yang tidak memiliki nilai akan mudah diserang oleh pesaing.

Menurut (Durianto, dkk, 2004) terdapat 5 dimensi yang menjadi penggerak utama pembentukan persepsi nilai terkait dengan kepuasan pelanggan, yaitu:

1) Dimensi kualitas produk

Kualitas produk merupakan penggerak kepuasan pelanggan yang pertama. Dalam dimensi kualitas produk paling tidak tercakup 5 elemen utama, yaitu kinerja, reliabilitas, fitur, keawetan, konsistensi, dan disain.

2) Dimensi harga

Bagi pelanggan yang sensitif, biasanya harga yang lebih murah bisa menjadi sumber kepuasan. 
3) Dimensi kualitas layanan

Kualitas layanan tergantung pada sistem, teknologi, dan manusia.

4) Dimensi emosional

Aspek emosional dapat menjadi salah satu faktor yang dapat mempengaruhi konsumen untuk membeli suatu produk.

5) Dimensi kemudahan

Pelanggan akan merasa semakin puas apabila pelanggan tersebut mendapatkan produk yang mudah dalam penggunaannya.

b. Kepribadian merek

Kepribadian merek dapat diartikan sebagai suatu hal yang dapat menghubungkan ikatan emosi merek tersebut dengan manfaat merek itu sendiri sebagai dasar untuk diferensiasi merek dan customer relationship yang pada akhirnya akan berujung pada keuntungan yang akan diraih oleh perusahaan. Seorang konsumen akan lebih tertarik untuk memilih suatu mereka apabila ia merasa bahwa kepribadian merek tersebut sesuai dengan yang diharapkan. Sebuah penelitian telah menemukan suatu skala yang dapat digunakan untuk mengukur kepribadian merek (Durianto, dkk, 2004), sebagai berikut:

1) Ketulusan (sederhana, jujur, sehat, riang).

2) Kegemparan (berani, bersemangat, penuh daya khayal, mutakhir).

3) Kecakapan (dapat dipercaya, cerdas, sukses).

4) Keduniawian (golongan atas, mempesona)

5) Ketangguhan (keras, ulet)

c. Asosiasi Organisasi

Asosiasi organisasi dapat dijadikan sebagai keunggulan kompetitif untuk mengembangkan persaingan pasar apabila merek tersebut tidak memiliki karakteristik yang dapat membedakan dengan merek pesaing. Sebuah perusahaan harus selalu menjaga asosiasi organisasinya dimata konsumen karena konsumen akan lebih tertarik untuk memilih merek yang diproduksi oleh perusahaan yang memiliki citra asosiasi organisasi yang baik. Selain itu, asosiasi organisasi akan sangat diperlukan untuk meningkatkan loyalitas konsumen terhadap merek tersebut. (Durianto, dkk, 2004) menyatakan 6 unsur yang dapat mempengaruhi asosiasi organisasi, yaitu sebagai berikut:

1) Orientasi pada masyarakat

Organisasi yang baik dapat dibuktikan melalui kepekaannya terhadap lingkungan, menjadi sponsor dalam kegiatan amal, memperlakukan karyawannya dengan baik, dan lain-lain.

2) Persepsi kualitas

Asosiasi organisasi dapat digunakan perusahaan sebagai sarana untuk menyampaikan pesan kepada konsumen bahwa merek tersebut memiliki kualitas yang dapat dipercaya.

3) Inovasi

Melalui inovasi, perusahaan dapat menampilkan merek yang terkesan lebih modern dan selalu mengikuti perkembangan pasar.

4) Perhatian kepada pelanggan

Perusahaan akan selalu mendapatkan konsumen diurutan pertama agar perusahaan tetap dapat menjaga hubungan jangka panjang dengan konsumen. 
5) Keberadaan dan keberhasilan

Kesuksesan suatu merek akan menciptakan rasa percaya diri terhadap konsumen yang telah memiliki produk tersebut.

6) Lokal versus global

Keputusan untuk mempersepsikan merek sebagai merek local atau global. Semakin banyak asosiasi yang saling berhubungan, maka akan semakin kuat citra mereknya. Selain itu, asosiasi merek dapat membangkitkan berbagai atribut produk atau manfaat bagi konsumen yang pada akhirnya akan memberikan alasan spesifik bagi konsumen untuk membeli dan menggunakan merek tersebut (Durianto, dkk, 2004).

\section{Persepsi Kualitas (Perceived Quality)}

Persepsi kualitas (perceived quality) merupakan persepsi pelanggan atas atribut yang dianggap penting baginya (Astuti dan Cahyadi, 2007). Terdapat 5 nilai yang dapat menggambarkan nilai nilai dari persepsi kualitas (Durianto, dkk, 2004)sebagai berikut:

a. Alasan untuk membeli

Persepsi kualitas yang baik dapat membantu periklanan dan promosi yang dilakukan perusahaan menjadi lebih efektif, yang akan terkait dengan keputusan pembelian oleh konsumen.

b. Diferensiasi atau posisi

Persepsi kualitas suatu merek akan berpengaruh untuk menentukan posisi merek tersebut dalam persaingan.

c. Harga optimum

Penentuan harga optimum yang tepat dapat membantu perusahaan untuk meningkatkan persepsi kualitas merek tersebut.

d. Minat saluran distribusi

Pedagang akan lebih menyukai untuk memasarkan produk yang disukai oleh konsumen, dan konsumen lebih menyukai produk

yang memiliki persepsi kualitas yang baik.

e. Perluasan merek

Persepsi kualitas yang kuat dapat dijadikan sebagai dasar oleh perusahaan untuk melaksanakan kebijakan perluasan merek.

Persepsi kualitas yang dimaksud dalam penelitian ini adalah persepsi pelanggan terhadap kualitas suatu merek produk. Persepsi kualitas ini akan membentuk persepsi kualitas secara keseluruhan terhadap suatu produk dibenak konsumen. Persepsi kualitas keseluruhan dari suatu produk dapat menentukan nilai dari produk atau jasa tersebut dan berpengaruh secara langsung kepada keputusan pembelian konsumen dan loyalitas merek terhadap merek (Durianto, dkk, 2004)

Persepsi kualitas yang positif akan mendorong keputusan pembelian dan menciptakan loyalitas terhadap produk tersebut. Hal itu karena konsumen akan lebih menyukai produk yang memiliki persepsi kualitas yang baik. Selain itu, konsumen juga merasa lebih yakin bahwa merek tersebut dapat menghindarkan mereka dari risiko pemakaian (Durianto, dkk, 2004).

Penelitian yang dilakukan oleh (Sri Wahjuni Astuti dan I Gde Cahyadi, 2007), menunjukkan hasil bahwa persepsi konsumen terhadap kualitas berpengaruh positif dan signifikan terhadap rasa percaya diri konsumen atas keputusan pembelian sepeda motor Honda di Surabaya, dengan nilai regresi 
sebesar 0,552. Hasil penelitiannya itu menunjukkan bahwa persepsi kualitas mempengaruhi rasa percaya diri pelanggan atas keputusan pembelian melalui keunikan atribut, karena menciptakan alasan yang kuat bagi pelanggan untuk membeli (reason to buy) yang dinilai mampu memenuhi desired benefit yang diinginkan pelanggan (Astuti dan Cahyadi, 2007)

\section{Loyalitas Merek (Brand Loyalty)}

a. Loyalitas

Menurut (Durianto, dkk, 2004) kepuasan adalah pengukuran secara langsung mengenai konsumen yang loyal terhadap suatu merek, sedangkan loyalitas merupakan hasil akumulasi dari pengalaman konsumen selama menggunakan produk.

Loyalitas merek dapat memberikan nilai kepada perusahaan, diantaranya adalah sebagai berikut (Durianto, dkk, 2004):

1) Mengurangi biaya pemasaran,

2) Meningkatkan perdagangan,

3) Menarik konsumen baru,

4) Memberi waktu untuk merespon ancaman persaingan.

b. Harga Optimum

Harga optimum adalah ukuran sampai seberapa tinggi konsumen bersedia membayar lebih untuk membeli suatu merek dibandingkan dengan merek lain. Harga optimum dapat dijadikan sebagai indikator untuk mengukur loyalitas konsumen terhadap suatu merek. Harga optimum mencerminkan kebijakan penetapan harga yang lebih dari pada harga pasar yang disebabkan oleh berbagai hal. Harga optimum merupakan satu-satunya pengukuran ekuitas merek yang terbaik karena pengukuran ini langsung mengetahui konsumen yang loyal terhadap suatu merek. Konsumen yang memiliki loyalitas tinggi akan bersedia untuk membayar harga yang lebih tinggi dari harga yang telah ditetapkan sebelumnya.

Loyalitas merek merupakan suatu ukuran keterkaitan pelanggan kepada sebuah merek. Ukuran ini mampu memberikan gambaran tentang mungkin tidaknya seorang pelanggan beralih ke merek lain, terutama jika pada merek tersebut didapati terjadinya perubahan baik menyangkut harga ataupun atribut lain (Durianto, dkk, 2004).

Konsumen yang memiliki loyalitas kuat terhadap suatu merek akan tetap melanjutkan pembelian produk tersebut, meskipun saat ini banyak bermunculan berbagai merek dipasar yang menawarkan karakteristik produk yang lebih unggul serta dapat memberikan jaminan peningkatan perolehan laba perusahaan di masa yang akan dating (Durianto, dkk, 2004)

\section{Promotion Mix \\ Advertising (Periklanan)}

Menurut (Wells Burnett dan Moriarty, 2003)Iklan adalah suatu bentuk komunikasi non-personal dengan biaya yang dikeluarkan oleh perusahaan dalam penggunaan media massa untuk membujuk dan mempengaruhi audiens. Sedangkan menurut (Kotler, 2003)iklan adalah bentuk penyajian non personal dan promosi ide, barang atau jasa oleh seorang sponsor tertentu yang perlu dibayar.Jika mengacu dari dua pendapat diatas, periklanan bisa dimaknai sebagai media komunikasi massa yang dibuat untuk tujuan mempengaruhi target pasarnya. Adapun obyek yang dikomunikasikan bisa berupa ide/gagasan, barang, 
jasa ataupun lainnya yang dilakukan oleh perusahaan, lembaga, institusi, atau siapapun juga.Melihat kenyataan di lapangan, memang hingga saat ini orangorang membeli sebuah produk sedikit banyak karena pengaruh iklan, baik iklan di televisi, radio, koran, majalah, spanduk, billboard di pinggir jalan, internet atau yang lainnya. Iklan-iklan tersebut selalu ada dan seolah selalu memberi peringatan kepada kita untuk selalu megingatnya.Tak bisa dipungkiri, iklan bisa menjadi salah satu media yang efektif untuk berkomunikasi dengan banyak orang.

Sales Promotion (Promosi Penjualan)

Menurut (Kotler, 2003), Promosi penjualan (Sales Promotion) adalah berbagai insentif jangka pendek untuk mendorong keinginan mencoba atau membeli suatu produk atau jasa. Sedangkan menurut (Lubis, 2004) Promosi Penjualan (Sales Promotion) adalah suatu kegiatan perusahaan untuk menjajakan produk yang dipasarkan sedemikian rupa sehingga konsumen akan mudah untuk melihatnya dan bahkan dengan cara penempatan dan pengaturan.

Public Realation and Publisity (Hubungan Massa)

Menurut (Cutlip, Center \& Broom, 2005) Public Relations adalah fungsi manajemen yang membangun dan mempertahankan hubungan yang baik dan bermanfaat antara organisasi dengan publik yang mempengaruhi kesuksesan atau kegagalan organisasi tersebut.Menurut Frank Jefkins, Public Relation adalah bentuk komunikasi yang terencana, baik itu ke dalam maupun ke luar, antara suatu organisasi dengan semua khalayaknya dalam rangka mencapai mencapai tujuan-tujuan spesifik yang berlandaskan pada saling pengertian. Sedangkan menurut (Kotler, 2003) Public Relations merupakan berbagai program untuk mempromosikan dan/atau melindungi citra perusahaan atau produk individualnya. Personal Selling (Penjualan Perorangan)

Menurut Norman A. Hart Dan John Stapleton, dalam kutipan (Komarudin Sastradipoetra, 2003: 194) Personal Selling adalah proses penyajian komersial secara lisan selama pembeli atau penjual dalam situasi wawancara. Sedangkan menurut (Kotler, 2003) Personal Selling adalah potensi lisan dalam pembicaraan dengan salah satu atau lebih calon pembeli untuk tujuan melakukan penjualan.

Direct Marketing (Pemasaran Langsung)

Menurut (Kotler dan Armstrong, 2008)Direct Marketing adalah pemasaran yang menggunakan berbagai media untuk berinteraksi langsung dengan konsumen, biasanya menelepon konsumen untuk mendapat respons langsung. Sedangkan menurut (Duncan, 2002) Direct Marketing adalah ketika perusahaan ingin menjalin komunikasi langsung dengan pelanggan, mereka mengguanakan strategi komunikasi langsung, dimana lebih bisa berinteraksi, database yang memicu proses komunikasi pemasaran menggunakan media untuk mendorong respon pelanggan.Direct Marketing bisa menjadi salah satu sistem pemasaran interaktif yang dapat dikembangkann perusahaan untuk menghasilkan tanggapan langsung dari pelanggan yang ditargetkan. Dengan melakukan dengan teknik promosi ini, pihak perusahaan akan mampu menciptakan hubungan baik dengan pelanggan.

\section{METODE PENELITIAN Jenis Penelitian}

Penelitian ini menggunakan pendekatan kuantitatif yang digunakan untuk menganalisis bagaimana satu variabel atau lebih berpengaruh terhadap 
variabel lain dan hubungan sebab-akibat antara variabel dijelaskan dengan hipotesis. Semua data dan informasi yang dikumpulkan dari responden menggunakan kuesioner dan kemudian hasilnya akan dijelaskan untuk menjawab pertanyaan penelitian. Penelitian ini bertujuan untuk menguji hipotesis. Hipotesis adalah studi yang menjelaskan sifat hubungan tertentu, atau membuat perbedaan diantara kelompok atau masing-masing dari dua atau lebih faktor dalam situasi (Sekaran, 2009). Jenis penelitian ini dipilih karena tujuan yang hendak dicapai mencakup usaha-usaha yang menjelaskan hubungan dan pengaruh yang terjadi antar variabel yang diteliti dengan mengumpulkan data melalui survey terhadap mahasiswa manajemen STIE-KBP padang, dan alat pengumpul data yang digunakan adalah kuesioner.

\section{Populasi dan Sampel}

Populasi merupakan keseluruhan objek penelitian. Penelitian ini akan menggunakan populasi yaitu sebanyak 625 mahasiswa. Sampel merupakan sebagian populasi yang akan diteliti atau sebagian dari jumlah karakteristik yang dimiliki oleh populasi (Sekaran, 2006).

Menurut (Sekaran, 2007), ukuran sampel yang lebih dari 30 dan kurang dari 500 adalah tepat untuk kebanyakan penelitian. Pengambilan sampel dilakukan dengan metode simple random sampling, dimana sample diambil berdasarkan proporsi responden masing-masing. Teknik ini digunkan bila populasi mempunyai anggota/unsur yang tidak homogen dan bersifat proportional (Sugiyono, 2003)

yaitu:

Jumlah sampel yang diambil dengan menggunakan rumus Slovin

Keterangan:

$$
\mathrm{n}=\frac{N}{1+\mathrm{Ne}^{2}}
$$

$\mathrm{n}=$ Number of samples (jumlah sampel)

$\mathrm{N}=$ Total population (jumlah seluruh anggota populasi)

$\mathrm{e}=$ Error tolerance $($ toleransi terjadinya kesalahan $10 \%=0,1$ )

maka besarnya sampel pada penelitian ini adalah :

$$
\mathrm{n}=\frac{625}{1+625(0,1)^{2}}=86,21
$$

Sampel yang dihasilkan sebanyak 86,21, kemudian dibulatkan menjadi 86 responden dari jumlah populasi.

\section{Definisi Operasional Variabel}

\section{Tabel 1}

\begin{tabular}{|c|c|c|}
\hline Variabel & Defenisi & Indikator \\
\hline $\begin{array}{l}\text { Brand Equity } \\
\text { (X1) }\end{array}$ & $\begin{array}{l}\text { Semakin kuat ekuitas merek } \\
\text { suatu produk, maka semakin } \\
\text { kuat pula daya tarik produk } \\
\text { dimata konsumen.untuk } \\
\text { memakai produk tersebut } \\
\text { dan mengarah pada } \\
\text { keputusan pembelian } \\
\text { produk. } \\
\text { (Durianto, dkk, 2004) }\end{array}$ & 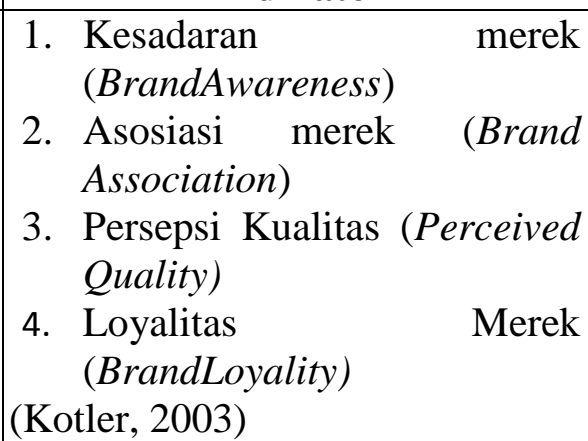 \\
\hline
\end{tabular}

Defenisi Operasional Variabel 


\begin{tabular}{|c|c|c|}
\hline $\begin{array}{l}\text { Promotion } \\
\text { Mix (X2) }\end{array}$ & $\begin{array}{l}\text { Mendefinisikan proses } \\
\text { keputusan pembelian adalah } \\
\text { keputusan pembeli tentang } \\
\text { merek apa yang akan dibeli. }\end{array}$ & $\begin{array}{l}\text { 1. Advertising (Periklanan) } \\
\text { 2. Sales Promotion (Promosi } \\
\text { penjualan) } \\
\text { 3. Public Realation And } \\
\text { Publicity (Hubungan massa) } \\
\text { 4. Personal selling ( Penjualan } \\
\text { Perorangan) } \\
\text { 5. Direct Marketing (Pemasaran } \\
\text { Langsung). } \\
\text { (Kotler, 2003) }\end{array}$ \\
\hline $\begin{array}{l}\text { Keputusan } \\
\text { Pembelian } \\
\text { (Y) }\end{array}$ & $\begin{array}{l}\text { Konsumen membeli merek } \\
\text { yang paling disukai, tetapi } \\
\text { duafaktor bisa berada antara } \\
\text { niat pembelian dan } \\
\text { keputusan pembelian(Kotler } \\
\text { dan Amstrong, 2008) }\end{array}$ & $\begin{array}{l}\text { 1. Kemantapan pada sebuah } \\
\text { produk. } \\
\text { 2. Yakin dalam membeli } \\
\text { produk. } \\
\text { 3. Memberikan rekomendasi } \\
\text { kepada orang lain. } \\
\text { (Kotler, 2007) }\end{array}$ \\
\hline
\end{tabular}

\section{Teknik Analisis Data}

\section{Uji Validitas}

Menurut (Nugroho, 2005: 67) untuk mengetahui kelayakan butir-butir dalam suatu daftar (konstruk) pertanyaan dalam mendefinisikan variabel. Jadi dapat dikatakan, semakin tinggi validitas suatu alat ukur maka alat ukur tersebut akan mengenai pada sasarannya. Suatu alat dapat dikatakan mempunyai validitas tinggi apabila dapat menjalankan fungsi ukurnya atau memberikan hasil ukur yang sesuai dengan maksud dan tujuan dari diadakannya tes atas penilaian tersebut. Penilaian kevalitan butir pertanyaan dapat dilihat dari Corrected ItemTotal Correlation masing-masing butir pertanyaan. Sehingga pengambilan keputusan adalah:

a. Jika Corrected Item-Total Correlation > 0,300 maka pertanyaan tersebut valid.

b. Jika Corrected Item-Total Correlation $<0,300$ maka pertanyaan tersebut tidak valid.

\section{Uji Reliabilitas}

Reliabilitas (reliability) adalah suatu alat pengukur yang menunjukkan akurasi, konsistensi dan ketepatan dari pengukurnya (Jogiyanto, 2004). Konsistensi menunjukkan seberapa baik item-ítem pernyataan yang mengukur sebuah konsep bersatu menjadi sebuah kumpulan (Sekaran, 2003) Suatu kuesioner dapat dikatakan reliabel jika jawaban seseorang terhadap pernyataan adalah konsisten dari waktu ke waktu (Cooper dan Schindler, 2006). Reliabilitas konstruk dalam penelitian ini akan diukur dengan menggunakan koefisien Cronbach Alpha. Suatu konstruk dikatakan reliabel jika nilai Cronbach Alpha di atas 0,60 (Nunnaly, 2004).

\section{Analisis Deskriptif}

Analisis deskriptif adalah analisis yang dilakukan untuk menilai karakteristik dari sebuah data.Anlisa ini bermaksud menggambarkan karakteristik masing-masing variabel penelitian.Analisa ini bertujuan untuk memperoleh gambaran objektif mengenai objek penelitian (Simamora, 2004 : 231). 


\section{Uji Asumsi Klasik}

Uji asumsi klasik bertujuan untuk mengetahui kondisi data yangdigunakan dalam penelitian.Hal tersebut dilakukan agar diperoleh model analisis yang tepat. Model analisis regresi penelitian ini mensyaratkan uji asumsi terhadap data yang meliputi :

\section{Uji Normalitas}

Uji normalitas bertujuan untuk menguji salah satu asumsi dasar analisis regresi berganda, yaitu variabel-variabel independen dan dependen harus berdistribusi normal atau mendekati normal (Ghozali, 2007).Uji normalitas residual dilakukan dengan menggunakan One Sample Kolmogorov-Smirnov test dengan taraf signifikan 5\%. Dasar pengambilan keputusan sebagai berikut:

1) Jika nilai Signifikan $>0,05$ maka dikatakan berdistribusi normal.

2) Jika nilai Signifikan $<0,05$ maka dikatakan berdistribusi tidak normal.

\section{Uji Multikolinearitas}

Uji multikolinearitas bertujuan untuk menguji apakah model regresi ditemukan adanya korelasi antar variabel bebas.Model regresi yang baik seharusnya tidak terjadi korelasi di antara variabel bebas.Jika variabel bebas saling berkorelasi, maka variabel-variabel ini tidak ortogonal.

Variabel ortogonal adalah variabel bebas yang nilai korelasi antar sesama variabel bebas sama dengan nol (0). Untuk mendeteksi ada atau tidaknya multikolinearitas di dalam model regresi adalah sebagai berikut (Ghozali, 2005):

1) Mempunyai angka Tolerance diatas $(>) 0,1$

2) Mempunyai nilai VIF di di bawah $(<) 10$

\section{Uji Heteroskedastisitas}

Uji heteroskedastisitas bertujuan menguji apakah dalam model regresi terjadi ketidaksamaan variance dari residual suatu pengamatan ke pengamatan yang lain. Jika variance dari residual satu pengamatan ke pengamatan lain tetap, maka disebut homokedastisitas. jika berbeda disebut heteroskedastisitas. Model regresi yang baik adalah homokedastisitas atau tidak terjadi heteroskedastisitas (Ghozali, 2005). Uji Glejser dilakukan dengan cara meregresikan antara variabel independen dengan nilai absolut residualnya

1) Jika nilai signifikansi antara variabel independen dengan absolut residual $>0,05$ maka tidak terjadi masalah heteroskedastisitas.

2) Jika nilai signifikansi antara variabel independen dengan absolut residual $<0,05$ maka terjadi masalah heteroskedastisitas.

\section{Analisis Regresi Linier Berganda}

Analisis regresi linier berganda digunakan untuk mengetahui ada tidak nya pengaruh variabel independent dengan variable dependent model atau persamaan analisis regresi berganda sebagai berikut (Ghozali, 2005) :

$$
\begin{array}{ll}
\text { Dimana : } \\
\mathrm{Y} & =\text { Keputusan Pembelian } \\
\mathrm{A} & =\text { Konstanta } \\
\mathrm{B} & =\text { Koefisien Regresi X } \\
\mathrm{X}_{1} & =\text { Brand Equity } \\
\mathrm{X}_{2} & =\text { Promotion mix } \\
\mathrm{e} & =\text { Standar error }
\end{array}
$$




\section{Uji Hipotesis}

\section{Uji Signifikan Simultan (Uji F)}

Dalam penelitian ini uji $F$ digunakan untuk mengetahui tingkat signifikansi pengaruh antara variabel-variabel independent terhadap variabel dependent(Ghozali, 2005) dalam penelitian ini hipotesis yang digunakan adalah : $\mathrm{H}_{0}$ : Tidak ada nya pengaruh Variabel $\mathrm{X}$ secara bersama-sama terhadap Variabel $\mathrm{Y}$ $\mathrm{H}_{\mathrm{a}}$ : Adanya pengaruh Variabel X bersama-sama terhadap Variabel Y.

Dasar pengambilan keputusan nya (Ghozali, 2005)adalah dengan menggunakan angka probabilitas signifikansi yaitu :

a. Apabila probabilitas signifikansi $>0.05$, maka $\mathrm{H}_{0}$ diterima dan $\mathrm{H}_{\mathrm{a}}$ ditolak

b. Apabila probabilitas signifikansi $<0.05$, maka $\mathrm{H}_{0}$ ditolak dan $\mathrm{H}_{\mathrm{a}}$ diterima

\section{Uji Signifikansi Pengaruh Parsial (Uji T)}

Uji T digunakan untuk menguji signifikan hubungan antara variabel $\mathrm{X}$ dan $\mathrm{Y}$ apakah dimensi variabel $\mathrm{X}\left(\mathrm{X}_{1}\right.$ : Brand Equity), $\mathrm{X}_{2}$ : Promotion Mix), benarbenar berpengaruh terhadap variabel Y (Keputusan Pembelian) secara terpisah atau parsial (Ghozali, 2005). Nilai dari uji $\mathrm{T}$ dapat dilihat dari p-value (pada kolom sig ) dengan pengujian hipotesis sebagai berikut :

a. Ho diterima dan Ha ditolak, jika t-hitung < t-tabel, atau nilai sig. > level of significant 0,05 yang menyatakan tidak adanya pengaruh yang signifikan antara Variabel X terhadap Variabel Y.

b. Ho ditolak dan Ha diterima jika t- hitung >t-tabel, atau nilai sig. < level of significant 0,05 yang menyatakan adanya pengaruh yang signifikan antara Variabel X terhadap Variabel Y.

\section{Koefisien Determinasi $\left(\mathbf{R}^{2}\right)$}

Koefisien determinasi $\left(\mathbf{R}^{2}\right)$ dimaksudkan untuk mengetahui tingkat ketepatan paling dalam analisis regresi dimana hal yang ditunjukan oleh besarnya koefisien determinasi $\left(\mathbf{R}^{2}\right)$ antara 0 (nol) dengan 1 (satu).koefisien determinasi nol, variabel independent sama sekali tidak berpengaruh terhadap variabel dependent. apabila koefisien determinasi semakin mendekati satu, maka dapat dikatakan bahwa variabel independent berpengaruh terhadap variabel dependent, selain itu koefisien determinasi dipergunakan untuk mengetahui persentase perubahan varibel Terikat (Y) yang disebabkaan oleh variabel bebas (X). Dalam penelitian ini, untuk mengolah data digunakan alat bantu SPSS versi 17. (Statistical Package for Social Science).

\section{PEMBAHASAN}

\section{Analisis Regresi Linier Berganda}

Variabel terikat pada regresi ini adalah Keputusan Pembelian (Y) sedangkan variabel bebasnya adalah variabel Brand Equity (X1), Promotion Mix (X2). 
Tabel 2

Koefisien Regresi Berganda

Coefficients $^{\mathrm{a}}$

\begin{tabular}{|c|c|c|c|c|c|c|}
\hline \multirow{2}{*}{\multicolumn{2}{|c|}{ Model }} & \multicolumn{2}{|c|}{ Unstandardized Coefficients } & \multirow{2}{*}{$\begin{array}{c}\begin{array}{c}\text { Standardized } \\
\text { Coefficients }\end{array} \\
\text { Beta }\end{array}$} & \multirow[b]{2}{*}{$\mathrm{t}$} & \multirow[b]{2}{*}{ Sig. } \\
\hline & & B & Std. Error & & & \\
\hline \multirow[t]{4}{*}{1} & (Constant) & 6.478 & .595 & & 10.882 & .000 \\
\hline & $\mathrm{X} 1$ & -.075 & .038 & -.747 & -1.971 & .052 \\
\hline & $\mathrm{X} 2$ & .011 & .042 & .107 & .262 & .794 \\
\hline & $\mathrm{Y}$ & .139 & .092 & .406 & 1.520 & .132 \\
\hline
\end{tabular}

a. Dependent Variable: DP

Sumber: Data diolah SPSS 2017

Berdasarkan table, maka dapatlah dikemukakan bentuk model persamaan regresi linier berganda untuk Keputusan Pembelian (Y) sedangkan variabel bebasnya adalah variabel Brand Equity (X1), Promotion Mix (X2) adalah sebagai berikut:

$$
\mathrm{Y}=6.478+0,075 \mathrm{X} 1+0,011 \mathrm{X} 2
$$

Penjelasan dari persamaan regresi linier berganda yang dihasilkan ini adalah sebagai berikut:

1. Nilai konstanta adalah 6.478 artinya nilai konstanta positif menunjukan adanya pengaruh variabel independent Brand Equity (X1), Promotion Mix (X2), terhadap variabel dependent Keputusan Pembelian ( Y).

2. Variabel Brand Equity (X1) memiliki koefisien sebesar 0,075 Ini menyatakan bahwa setiap penambahan 1 Brand Equity, maka nilai Keputusan Pembelian bertambah sebesar 0,075.

3. Variabel Promotion Mix (X2) memiliki koefisien sebesar 0,011, Ini menyatakan bahwa setiap penambahan 1 Promotion Mix, maka nilai Minat beli bertambah sebesar 0,011 .

\section{Uji Hipotesis}

\section{Uji Koefisien Regresi Secara Simultan Uji F}

Uji simultan hubungan Keputusan Pembelian, Brand Equity, dan Promotion Mix terhadap Minat beli di Smartphone Xiomi adalah untuk melihat apakah kedua variabel bebas yang dilakukan dengan pengujian menggunakan statistik Uji F yang dihitung melalui tabel Anova. Hasil perhitungan statistik Uji F dengan menggunakan bantuan software SPSS sebagai berikut:

\section{Tabel 3}

Uji Regresi Secara Simultan (Uji F)

ANOVA $^{\mathrm{D}}$

\begin{tabular}{|ll|r|r|r|r|r|}
\hline Model & Sum of Squares & Df & Mean Square & F & Sig. \\
\hline 1 & Regression & 18.805 & 3 & 6.268 & 3.469 & $.020^{\mathrm{a}}$ \\
& Residual & 148.184 & 82 & 1.807 & & \\
& Total & 166.988 & 85 & & & \\
\end{tabular}

a. Predictors: (Constant), Y, X1, X2

b. Dependent Variable: DP

Sumber: Data diolah SPSS 2017 
Pengujian pengaruh variabel bebas secara bersama-sama terhadap variabel terikatnya dilakukan dengan menggunakan uji F. Hasil perhitungan statistik menunjukkan nilai signifikansi sebesar $0,020<0,05$. Artinya secara simultan variabel bebas (Brand Equity,dan Promotion Mix) berpengaruh signifikan terhadap variabel terikat (Keputusan Pembelian).

\section{Uji Koefisien Regresi Secara Parsial (T)}

Uji $\mathrm{T}$ digunakan untuk melihat sejauh mana pengaruh secara parsial masing-masing variabel bebas (independen) terhadap variabel terikat (dependen).Berdasarkan hasil perhitungan regresi yang dilakukan diperoleh nilai koefisien parsial dari masing-masing variabel independen sebagaimana terlihat pada tabel dibawah ini:

Tabel 4

Ringkasan Pengujian Variabel Independen Terhadap Variabel Dependen (Secara Parsial T)

Coefficients $^{a}$

\begin{tabular}{|c|c|c|c|c|c|c|}
\hline \multirow{2}{*}{\multicolumn{2}{|c|}{ Model }} & \multicolumn{2}{|c|}{ Unstandardized Coefficients } & \multirow{2}{*}{$\begin{array}{c}\text { Standardized } \\
\text { Coefficients }\end{array}$} & \multirow[b]{2}{*}{$\mathrm{t}$} & \multirow[b]{2}{*}{ Sig. } \\
\hline & & $\mathrm{B}$ & Std. Error & & & \\
\hline \multirow[t]{4}{*}{1} & (Constant) & 6.478 & .595 & & 10.882 & .000 \\
\hline & $\mathrm{X} 1$ & -.075 & .038 & -.747 & -1.971 & .052 \\
\hline & $\mathrm{X} 2$ & .011 & .042 & .107 & .262 & .794 \\
\hline & $\mathrm{Y}$ & .139 & .092 & .406 & 1.520 & .132 \\
\hline
\end{tabular}

a. Dependent Variable: DP

Sumber: Data diolah SPSS 2017

Berdasarkan hasil tabel, pengaruh secara parsial masing-masing variabel bebas (independen) terhadap variabel terikat (dependen).

a. Brand Equity (X1) terhadap Keputusan Pembelian (Y)

Dengan nilai signifikan 0,052 lebih besar dari nilai 0,05 (0,052>0,05), Nilai $\mathrm{t}=1.971$ positif menunjukkan bahwa variabel Brand Equity mempunyai hubungan yang searah dengan Y. Maka Hipotesis (H1) diterima, Jadi dapat disimpulkan Brand Equity memiliki pengaruh positif signifikan terhadap Pembelian Smartphone Xiomi.

b. Promotion Mix (X2) terhadap Keputusan pembelian (Y)

Dengan nilai signifikan 0,794 lebih Besar dari nilai level of sig 0,05 $(0,794>0,05)$ Nilai $t=0,262$ positif menunjukkan bahwa Persepsi manfaat mempunyai hubungan yang searah dengan Keputusan Pembelian. Maka Hipotesis (H2) diterima dan dapat disimpulkan Promotion Mix memiliki pengaruh Positif signifikan terhadap Pembelian Smartphone Xiomi.

Uji Koefisien Determinan Uji $\mathbf{R}^{2}$

Koefisien determinasi $\left(\mathrm{R}^{2}\right)$ ini digunakan untuk mengetahui seberapa besar variabel-variabel bebas memiliki pengaruh terhadap variabel terikatnya. Nilai koefisien determinasi untuk variabel bebas digunakan adjusted $R$ square, sebagai berikut 
Tabel 5

Model Summary ${ }^{\mathrm{O}}$

Koefisien Determinasi $\left(\mathbf{R}^{2}\right)$

\begin{tabular}{|l|r|r|r|r|}
\hline Model & \multicolumn{1}{|c|}{$\mathrm{R}$} & $\mathrm{R}$ Square & $\begin{array}{c}\text { Adjusted R } \\
\text { Square }\end{array}$ & $\begin{array}{c}\text { Std. Error of } \\
\text { the Estimate }\end{array}$ \\
\hline 1 & $.336^{\mathrm{a}}$ & .113 & .080 & 1.34429 \\
\hline
\end{tabular}

a. Predictors: (Constant), $\mathrm{Y}, \mathrm{X} 1, \mathrm{X} 2$

b. Dependent Variable: DP

Sumber: Data diolah SPSS 2017

Dari tabel diatas maka diketahui nilai Adjusted R Square adalah sebesar 0,080.Dari nilai tersebut dapat dilihat bahwa Keputusan Pembelian dipengaruhi oleh Brand Equity dan, Promotion Mix sebesar 0,080.

\section{Pengaruh Brand Equity Terhadap Keputusan Pembelian Smartphone Xiomi}

Hasil penelitian ini menunjukan nilai signifikan Brand Equity 0,052>0,05 dengan nilai koefisien regresi sebesar 0,075 dan nilai t hitung 1,971 karena nilai koefisien regresi Brand Equity bernilai positif, maka Hasil penelitian ini menunjukan Brand Equity berpengaruh positif terhadap Keputusan Pembelian Smartphone Xiomi ,dengan setiap peningkatan Brand Equity ditentukan oleh semakin tingginya Keputusan Pembelian Smartphone Xiomi. Semakin kuat ekuitas merek suatu produk,maka semakin kut pula daya tariknya dimata konsumen untuk mengkonsumsi produk tersebut dan pada akhirnya akan mengarah pada keputusan pembelian produk (Durianto, dkk, 2004). Keputusan pembelian Smartphone Xiomi, menyatakan bahwa Brand Equity berpengaruh positif dan signifikan terhadap Keputusan Pembelian Smartphone Xiomi, dari nilai t hitung sebesar 1,971 dengan nilai signifikasi sebesar 0,052.

Pengaruh Promotion Mix Terhadap Keputusan Pembelian Smartphone Xiomi

Hasil penelitian ini menunjukan nilai signifikan Promotion Mix 0,794>0,05 dengan nilai koefisien regresi 0,011 dan nilai t hituing nya 0,262 karena nilai koefisien regresi Promotion Mix bernilai positif, maka Hasil penelitian menyatakan Promotion Mix berpengaruh positif terhadap Keputusan Pembelian, berarti setiap peningkatan Promotion Mix ditentukan oleh semakin meningkatnya Keputusan Pembelian Smartphone Xiomi. Penelitian ini mendukung teori tentang Promotion Mix Menurut (Yoeti, 2006).Promotion Mix adalah bermacam-macam cara atau kegiatan promosi yang dilakukan untuk mempengaruhi target pasar, meskipun bentuk-bentuk promosi memiliki fungsi yang sama, tetapi bentuk-bentuk tersebut dapat dibedakan berdasarkan tugas-tugas khususnya. Hasil penilitian dari nilai koefisien regresi 0,011 dan t-hitung sebesar 0,262 dengan signifikasi sebesar 0,794.Jadi dapat disimpulkan Promotion Mix berpengaruh positif dan signifikan terhadap Keputusan Pembelian Smartphone Xiomi.

\section{SIMPULAN}

Berdasarkan hasil pembahasan dapat disimpulkan bahwa model hipotesis yang dibangun dalam penelitian ini dapat terbukti, sehingga dapat diketahui hubungan antara Brand Equity dan Promotion Mix terhadap Keputusan Pembelian Smartphone Xiomi, sebagai berikut : 
1. Dengan nilai signifikan $0,052>0,05$ dengan Nilai $t=1,971$ positif menunjukkan bahwa variable Brand Equity mempunyai hubungan yang searah dengan Keputusan Pembelian, Maka hipotesis H1 dapat diterima, Disimpulkan Brand Equity memiliki pengaruh positif dan signifikan terhadap Keputusan Pembelian Smartphone Xiomi.

2. Dengan nilai signifikan $0,794>0,05$ dengan Nilai $t=0,262$ positif menunjukkan bahwa variabel Promotion Mix mempunyai hubungan yang searah dengan Keputusan Pembelian. Maka Hipotesis H2 dapat diterima, Jadi disimpulkan Promotion Mix memiliki pengaruh Positif dan signifikan terhadap Keputusan Pembelian Smartphone Xiomi.

\section{DAFTAR PUSTAKA}

Andika, A., \& Susanti, F. (2018). Pengaruh Marketing Mix Terhadap Keputusan Pembelian Parfum di Azzwars Parfum Lubeg Padang. https://doi.org/10.31227/osf.io/upgc3

Armstrong dan Philip Kotler. 2003. ManajemenPemasaran,Edisi Kesembilan. Jakarta: PT.Indeks Gramedia

Aziz, N. (2019). Pengaruh Strategi Promosi Terhadap Keputusan Pembelian Yang Dimediasi Oleh Minat Beli Pada Konsumen Restoran KFC Cabang Khatib Sulaiman Padang. https://doi.org/10.17605/OSF.IO/V92TS

Aziz, N. (2019). Analisis Pengaruh Kualitas Produk, Harga, Promosi Terhadap Keputusan Pembelian Air Minum Dalam Kemasan (AMDK) Merek Aicos Produksi Pt. Bumi Sarimas Indonesia. https://doi.org/10.17605/OSF.IO/8XKYB

Duane E. Knapp. 2001. The Brand Mindset. Edisi Kedua. Yogyakarta: Andi.

Durianto, Darmadi, Sugiarto dkk, 2004, Brand Equity Tren Strategy Memimpin Pasar,PT.Gramedia Pustaka Utama: Jakarta

Hidayati, R. R., \& Marlius, D. (2018). Aktivitas Promosi Dalam Meningkatkan Dana Pihak Ketiga Pada PT. Bank Perkreditan Rakyat (BPR) Batang Kapas Pesisir Selatan. https://doi.org/10.31227/osf.io/8dgqn

Humdiana. 2005. Strategi Pemasaran. Jakarta: PT. Gramedia Pustaka Mizan Pustaka.

Jamarnis, S., \& Susanti, F. (2019). Pengaruh Harga Dan Periklanan Melalui Internet Terhadap Keputusan Pembelian Produk Sabun Merek Lux Pada Mahasiswa STIE “KBP” Padang. https://doi.org/10.31227/osf.io/xz3d8

Kotler, Philip, 2005, ManajemenPemasaran, Jilid I dan II, PT. Indeks, Jakarta 
Kotler, Philip, 2007, Manajemen Pemasaran, Jilid 2, Edisi 12, PT Indeks., New Jersey.

Kotler, Philip dan Armstrong, Gary. (2011). 10 Edition. "Marketing an Introduction". Indonesia: Perason

Lindawati. 2005. Analisis Kesadaran Merek, Persepsi Kualitas, dan Asosiasi Merek dalam Ekstensi Merek pada Produk Merek "Lifebouy" di Surabaya.Jurnal Sains Pemasaran Indonesia. Vol. 4 (1). hal. 47-70.

Mangold, WG. and Faulds, DJ. (2009). Social Media: The New Hybrid Element of The Promotion Mix

Marlius, D. (2017). Keputusan Pembelian Berdasarkan Faktor Psikologis Dan Bauran Pemasaran Pada PT. Intercom Mobilindo Padang. Jurnal Pundi. Volume 1. No. 1. Hal. 57-66. https://doi.org/10.31575/jp.v1i1.9

Marlius, D. (2016). Pengaruh Bauran Pemasaran Jasa Terhadap Minat Nasabah Dalam Menabung Pada Bank Nagari Cabang Muaralabuh. https://doi.org/10.31227/osf.io/vdqgx

Mayliza, R. (2019). Pengaruh Citra Perusahaan (Corporate Image) Dan Penanganan Keluhan (Complaint Handling) Terhadap Loyalitas Pelanggan (Loyality) Natasha Skin Care Di Kota Padang. https://doi.org/10.17605/OSF.IO/DF9XJ

Mayliza, R. (2019). Pengaruh Kesadaran Merek, Asosiasi Merek Dan Perception Of Quality Terhadap Keputusan Pembelian Hospital Bed Merek Paramout Di PT. Aga Medika Utama Padang (Studi Kasus Rumah Sakit Umum Kota Padang). https://doi.org/10.17605/OSF.IO/VYQ4E

Mayliza, R. (2019). Analisis Keputusan Pembelian Ulang Axis Ditinjau Dari Bauran Pemasaran Kasus Di Kota Padang. https://doi.org/10.31219/osf.io/e7xhy

Mursid, M. 2006. Manajemen Pemasaran. Cetakan ke Empat. Jakarta ; PT. Bumi Aksara.

Pranata, H. I., \& Mayliza, R. (2019). Pengaruh Komunikasi Pemasaran Terpadu Dan Ekuitas Merek Terhadap Loyalitas Konsumen Pada CV. Laris Motor Cabang Air Haji. https://doi.org/10.31219/osf.io/d9qsu

Sekaran, Uma. 2009.Research Methods for Business :MetodologiPenelitian untuk Bisnis. Edisi 4.Buku 1. Jakarta: Salemba Empat.

Setiadi, Nugroho J. 2003, Perilaku Konsumen. Kencana. Jakarta.

Sugiyono. 2003. Metode Penelitian Bisnis. Edisi 1, Bandung: Alfabeta 
Susanti, F. (2015). Pengaruh Bauran Promosi Terhadap Keputusan Klien Dalam Memilih Radio Carano Sebagai Media Promosi Iklan. https://doi.org/10.31227/osf.io/b9ws7

Susanti, F., \& Gunawan, A. C. (2019). Pengaruh Bauran Promosi Dan Harga Terhadap Keputusan Pembelian Produk Kosmetik Maybelline Di Kota Padang. https://doi.org/10.31227/osf.io/npjqh

Widayati, R. (2019). Aktivitas Pemasaran Produk Simpanan PT. Bank Tabungan Negara (Persero) Tbk Kantor Cabang Padang. https://doi.org/10.17605/OSF.IO/3Z5YC 